\title{
Chapter 10 \\ Teachers and Administrators as Lead \\ Professionals for Democratic Ethics: \\ From Course Design to Collaborative Journeys of Becoming
}

\author{
Daniel J. Castner, Rosemary Gornik, James G. Henderson, \\ and Wendy L. Samford
}

\begin{abstract}
The heightened level of attention being afforded to "teacher leadership" is palpable in the United States. At a national level, proprietary organizations are receiving funds from large philanthropic organizations (e.g., the Gates and the Wallace Foundations) to promote the development of teacher leaders. State departments of education are accommodating the federal push finding various ways to incentivize the efforts of teachers to lead from the classroom. Our institutions of higher education are also adjusting and accommodating by taking up the charge of preparing teacher leaders, theorizing, and researching the potential of teacher leadership through academic study. As professors of education in the United States, we are mindful of the contextualizing neoliberalism infused throughout our policy environment and are deeply concerned about the habits of competition, rigidness, bureaucratization, and overspecialization. Not surprisingly, such ways of thinking, acting, and being infiltrate our educational institutions and can have a dehumanizing effect on local teachers, their pedagogies, and their students (Noddings 2007; Nussbaum 2010). Such habits of mind and body can additionally reinforce a sense of isolation between teachers and their profession (Eisner 2001), perhaps even a loss of vocational calling (Hansen 1995; Palmer 2007). Along with this can come a sense of alienation from colleagues and administrators (Macdonald and Shirley 2009) as well as a loss of individual and collective voice and autonomy (Apple 2006; Ayers 2010; Miller 1990). This chapter reports on an action research project designed focused on teacher leadership and reconceptualist curriculum theorizing as an alternative to the Tyler Rationale.
\end{abstract}

\footnotetext{
D.J. Castner $(\bowtie)$

Bellarmine University, Louisville, KY, USA

e-mail: dcastner@bellarmine.edu

R. Gornik • J.G. Henderson • W.L. Samford

Kent State University, Kent, OH, USA

e-mail: rgornik@kent.edu
} 


\section{Introduction}

This collaboratively authored chapter is centered on the scholarly personal narratives of four educators, who maintain a faithful commitment to the integration of democracy and education a century after the publication of Dewey's (1916) seminal text. Their stories converge around a course at Kent State University that introduces fundamentals of curriculum to graduate students. Through the disciplined study of curriculum in this course, the taken-for-granted ideas that routinely circulate as common sense in many educators' habituated thoughts, discourse and daily practices are disrupted and personal pathways for new semiotic understandings are constructed. In specific terms, technical understandings of the fundamentals of curriculum, as symbolized by Tyler's (1949) "rationale," are critically challenged in light of a key normative question: what are educators' ethical responsibilities as lead professionals in societies with democratic aspirations, and how ought they to function in contemporary educational institutions that promulgate value-neutral decision-making?

This chapter begins with Jim Henderson's narrative of 25 years of action research in the curriculum fundamentals course, which has resulted in the creation of a constructive alternative to Tyler's rationale through a reconceptualization of curriculum development. Next, Dan Castner shares how his understanding of Jim's action research has informed his theory and practice of curriculum-based teacher leadership. Rosemary Gornik and Wendy Samford then discuss how their ongoing semiotic engagement with the fundamentals of curriculum wisdom has been applied to a grant project addressing the interplay of administrative and teacher leadership. Collectively, these narratives present a picture of educators engaged in collaborative journeys of becoming for the purpose of establishing an ethical community of democratic visionaries, colleagues and pedagogical artists.

\section{Jim Henderson: Course Design}

A Kent State University (KSU) graduate course, entitled "Fundamentals of Curriculum," (FoC) has been serving as my de facto research laboratory since 1991. It's been the place where I have been diligently refining a constructive alternative to Ralph Tyler's (1949) "rationale" which, despite the fact that it was published 67 years ago, is still considered the paradigmatic exemplar for conceptions of curriculum development (Null 2008; Walker and Soltis 2009). While teaching the FoC course for 25 years, I have examined and explored an open set of potentially fruitful curriculum concepts through informal action research activities, and I have been quite open and honest about my experimental approach. I tell students that I have had no other choice since what local school district would support such trial-anderror efforts? 
FoC is the core course in KSU's Curriculum and Instruction (C\&I) M.Ed. Program. This masters' degree program has seven subject-area concentrations and also serves as a key professional development course for non-C\&I students such as nurses and business people. In addition, $\mathrm{FoC}$ is a recommended course for new $\mathrm{C} \& \mathrm{I}$ Ph.D. students. As a result, the course is offered at least twice a year and draws on a diverse student population. I have taught FoC over 60 times during the past 25 years.

I have now reached the point in my ongoing FoC action research that I can confidently state that, with the help of my students in the course as well as many collaborating colleagues, I can now present a constructive alternative to Tyler's rationale. It's not surprising that it's taken me so long to get to this point, given the philosophical, personal, social and political challenges involved. In fact, when I started my experimental work in 1991, I didn't even fully understand these challenges. I do now; and as I have proceeded with my action research over the years, three broad ethical themes have emerged to guide my work: critical pragmatism, democratic hermeneutics, and holistic pedagogy. The themes are conceived as an open set of ethical end-in-views, not as a precise code of ethics, which allows for the play of diversified interpretations characteristic of democratic conversations and deliberations. As I introduce the three normative themes, I will be integrating nine concepts into my discussion. These nine concepts, which are presented in the FoC course as nine fundamentals of curriculum, provide scaffolding for the ethical mindfulness that I am advancing. In short, the FoC course is designed so that the three broad ethical orientations are grounded in a conceptual understanding agenda.

Critical Pragmatism The starting point for my years of FoC action research is the critical recognition that Tyler's rationale lacks a strong ethical basis. Tyler argues that educational workers need to systematically address the relationship between identifying clear curriculum purposes, designing learning experiences that address these purposes, organizing these experiences in accessible and coherent ways, and evaluating the learning results with the implication that curriculum development adjustments may need to be made. In effect, Tyler provides scaffolding for a seemingly thoughtful and recursive problem solving circuit. Herbert Kliebard-arguably the most influential and incisive North American critic of Tyler's rationale-notes that Tyler's purpose-experience-organization-evaluation circuit is, in fact, an "imperishable" feature of his curriculum development approach. Kliebard (1992) writes:

One reason for the success of the Tyler rationale is its very rationality. It is an eminently reasonable framework for developing a curriculum; it duly compromises between warring extremes and skirts the pitfalls to which the doctrinaire are subject. In one sense the Tyler rationale is imperishable. (p. 164)

It took me years to conceive of a constructive way to acknowledge the enduring relevance of Tyler's recursive problem solving while establishing critical distance from his inattentive ethics. I didn't want to throw the baby out with the bathwater. As Cherryholmes (1988) illustrates, Tyler's rationale is an example of "vulgar," not "critical," pragmatism. He writes: 
Tyler's proposal was attractive because it promised order, organization, rationality, error correction, political neutrality, expertise, and progress....[Unfortunately], the rationale is incomplete when it comes to making decisions about curriculum and instruction... There is no discussion of...politics, ethics, social criticism, social responsibility, or critical reflection (pp. 26, 40-41).

Tyler does not advance a deep critical and ethical awareness of curriculum purposes and practices. Any purpose can be plugged into his problem solving circuit: teaching dogmatic beliefs, teaching racism and sexism, teaching to standardized tests, etc. As the years progressed and I continued to think about this underlying normative-philosophical problem, I kept coming back to Dewey's (1897/2013) statement that teaching is "the supreme art" in a society.

Though space does not allow me to share my years of evolving critical and creative work on the organizing idea that teaching is a society's supreme art, I can state my current perspective on this matter. Educators become 'supreme' artists when they work on being lead professionals in their society for democratic ethics-when they cultivate a particular personal-professional journey of becoming. Here's how I present this perspective in my current FoC syllabus:

$* * * * * *$

In this course, "curriculum" will be defined as the deep-seated study and practice of the relationships between the what, the how, and the why of educational courses of action. Building on this definition, 'good' curriculum work will be interpreted as the study and practice of the relationship between educational courses of action and democratic living, particularly as informed by the writings of the great American educational philosopher, John Dewey. On the eve of World War II-in the context of America's upcoming fight with German Fascism, Japanese Imperialism, and Soviet Communism-Dewey wrote, "We [Americans] have advanced far enough to say that democracy is a way of life: What happened since...? We have yet to realize that it is a way of personal life and one which provides a moral standard for personal conduct" (Dewey 1939/1989, p. 101).

The eighteenth-century founders of the United States thought deeply about the quality of political and legal problem solving but gave insufficient attention to the quality of curriculum problem solving. If their constitutional work had been informed by disciplined curriculum studies (which did not formally emerge in the United States until 1918), they would have recognized the long-term societal implications of Dewey's (1897/2013) position that,

Education... marks the most perfect and intimate union of science and art conceivable in human experience. The art of thus giving shape to human powers and adapting them to social service is the supreme art; one calling into its service the best of artists; that no insight, sympathy, tact, executive power, is too great for such service. Every teacher should realize the dignity of his [or her] calling; that he [or she] is a social servant set apart for the maintenance of proper social order and the securing of the right social growth. (pp. 39-40)

In curriculum studies language, this historic limitation has created a profound "null curriculum" problem for the United States that has important implications for 
all societies with democratic aspirations, ideals, and/or social contracts. The "null curriculum" notion refers to educational topics that are ignored but should be taught. Eisner (1994) explains:

It is my thesis that what schools do not teach may be as important as what they do teach. Ignorance is not simply a neutral void; it has important effects on the kind of options one is able to consider, the alternatives that one can examine, and the perspectives from which one can view a situation or problems. The absence of a set of considerations or perspectives or the inability to use certain processes for appraising a context biases the evidence one is able to take into account. A parochial perspective or simplistic analysis is the inevitable progeny of ignorance. (p.158)

This course is designed to address the problem of underdeveloped ethical understanding and mindfulness in curriculum decision-making. You will be treated as having the potential to serve as one of your society's lead professionals for democratic ethics. In this course, you will not be treated as compliant, non-thinking semiprofessionals but as trustworthy professionals capable of visionary, informed ethical judgments based on disciplined study and practice. Acknowledging certain caveats, this is how Finnish educators are treated in their society (Sahlberg 2015). This is my relationship promise to you.

$* * * * * *$

Tero Autio's critique of the epistemological foundations of Tyler's rationale, as well as the many similar, modernist curriculum development processes, provides important pragmatic insights into the consequences of promoting value-free procedures. Autio (2006) notes that,

The aims and objectives pioneers [in the field of curriculum studies] gave to curriculum discourse....behavioral, scientific job analysis. The introduction of precise scientific methods in educational practice, drawing especially from industry...has been expanded to an ambitious, relatively autonomous and highly detailed classification of objectives.... At the center of this [work]...remains Ralph Tyler. His contribution was to capture the spirit and letter of the instrumental symbolic curriculum.... This aims-and-objectives movement, in which Tyler focused its scrutiny on the definition of curricular objectives, has been replaced by the neoliberal interest in the assessment of objectives by an intensified monitoring of individual performativity. (p. 13)

Autio (2006) then concludes his thorough, historical critique with a "dusting" metaphor, "The efforts to rescue education and educative experience from the stranglehold and seductions of vulgar instrumentalism is parallel to the act of dusting: There is a constant need for cleaning; dust never disappears completely" (p. 162). In the FoC course, I began working with the concept of curriculum criticism to refer to this continuous dusting.

The particular dusting that Autio (2015) has in mind is the establishment of critical distance from a "calculative instrumentality" embedded in a "culture of Method" in order to embrace and refine ethical values. He writes:

Scratch a good teacher and you will find a moral purpose. At its best, an emphasis on the moral shifts teaching from transmission to transformation, as the curriculum is no longer test preparation but a complicated conversation where all participants at every level think 
about the basic curriculum questions regarding the worth of and interconnections between the subject matter and the related subjective and social dynamics (pp. 180-181, 195).

This shift from transmission to transformation became a key focus in my FoC pedagogy as I began to think deeply about the concept of transformative curriculum leadership, which ultimately resulted in the creation of three editions of a coauthored text using the concept as the title of the book. The third edition of Transformative Curriculum Leadership provides the clearest definition of the concept:

Burns (1978) describes transformative leaders as individuals who encourage "principled levels of judgment" through dedicated effort (p.455). They inspire others to higher levels of performance. Because transformative curriculum leaders care so deeply about the facilitation of a personalized 3S [subject, self and social] understanding, they affirm the "best selves" of those who are around them (Noddings 1984). Burns (1978) contrasts transformative leadership with a more traditional understanding of leadership, with its focus on the efficient attainmentof organizational goals and not on "consciousness raising on a wide plane" (p.43) (Henderson and Gornik 2007, p.17).

In short, the concept of transformative curriculum leadership three key personalprofessional questions:

- Am I encouraging the establishment of critical distance from all personal and social factors that work against honest self-examination and visionary microand macro-cultural change?

- Am I inspiring best-self contemplations and deliberations?

- Am I fostering principled, deliberative judgments?

Because I recognized early on in the FoC course that the pursuit of these critical questions required the cultivation of a personal-professional journey of deepening understanding, I incorporated Pinar and Grumet's (1976) reframing of the Latin noun 'curriculum' as the Latin gerund, currere. In interpreting curriculum-ascurrere, Pinar and Grumet highlighted the relationship between an individual's personal past, present, and future when 'running' any particular educational course of action - a relationship that invited autobiographical narrative. In a later publication, Pinar (1994) summarizes the composition of currere narratives with a particular organizing question: "How is the future present in the past, the past in the future, and the present in both?" (p. 26). As Rosemary Gornik and I created the third edition of Transformative Curriculum Leadership, we decided that each of the nine chapters of the book would end with a specific currere narrative that she would compose from the perspective of a democratically-oriented educational practitioner who was committed to embodying and enacting inspired, deliberative judgments.

Over time, I came to realize that, with reference to educators becoming lead professionals for democratic ethics, my pedagogical focus was on journeys of understanding that positioned teachers to practice another key conceptual referent: $3 S$ pedagogy. $3 \mathrm{~S}$ pedagogy is an abbreviated shorthand way to refer to teaching for Subject understandings that are embedded in democratic Self and Social understandings. I first published this $3 S$ teaching notion in the third edition of my reflective teaching text (Henderson 2001a), and I was pleasantly surprised at how well it 
caught on in the FoC course. As a result, I have continued to refine the concept over the years; and in the first chapter of my latest collaborative text, I open with four snapshots of $3 \mathrm{~S}$ pedagogy composed by a kindergarten, a grade school, a high school and a college teacher. I introduce their four brief narratives as follows:

[Dan, Chris, Boni, and Beth] present four snapshots of their holistic teaching, which they see as personalized embodiments of their institutions' mission statements and their country's democratic aspirations. They hope that their individualized snapshots are instructive and, possibly, inspirational. Collectively, these four narratives are reminders that many educators feel they have a noble vocational calling which they understand in their own terms. There are many educators who don't see themselves as bureaucratic functionaries, corporate employees, or compliant technocrats. They view themselves as lead professionals with important visionary, progressive responsibilities. In broader cultural and policy terms, countries that do not recognize such educators' vital role in the dynamic health of their societies may be condemning their current and future generations to stagnant, regressive, and rigid lives (Henderson et al. 2015, pp. 1-2).

To summarize my pedagogical discussion to this point, the creation of a constructive alternative to Tyler's rationale required me to think through the vital academic, personal and social relationships between curriculum criticism, transformative curriculum leadership, currere narrative, and $3 \mathrm{~S}$ pedagogy. As I refined my thinking on this conceptual gestalt, I realized that this transformative work requires disciplined study; and hence, educators who are inclined to provide collegial leadership for this disciplined study should think of themselves as lead learners. Working with an international team of eighteen educators, I created a lead-learning text that would be incorporated into my FoC pedagogy. The book, entitled Reconceptualizing Curriculum Development (RCD), is based on Pinar's (2006) argument that disciplined studies, not technical protocols, should be the basis for rethinking curriculum development. Pinar writes:

Before the Reconceptualization, curriculum development was primarily procedural, epitomized in Tyler's (1949) four questions. ..[These many] years after the Reconceptuali-zation, I am proposing curriculum development that is simultaneously... [study-based]. ... As a curriculum developer, I compose synpotic texts to enable public school teachers to reoccupy a vacated public domain, not as "consumers" of knowledge, but as active participants in complicated conversations that they themselves will lead in their own classrooms. In drawing widely but critically from various academic disciplines, from interdisciplinary areas, from popular culture, the form of curriculum development I propose and demonstrate herein creates textbooks for teachers who can appreciate that our professional calling is the intellectual reconstruction of the public and private spheres (p. x).

The concept of lead learning is presented a certain way in the RCD text. Lead learning is defined as the formal and/or informal study of relevant curriculum and pedagogy topics that is initiated and modeled by one educator who then personally invites interested colleagues to join him or her. Lead learning does not require expertise; it only requires a willingness to engage in study relationships. Lead learning is decidedly non-hierarchical. It is highly collaborative and allows for diversified, idiosyncratic, and existential understandings. Barth (2008) writes that, "In our [education] profession, especially, one is a learner and THEREBY a leader. The moral authority of the educational leader comes first and foremost from being a 
learner" (p. x). Lieberman and Friedrich (2010) note that there are, increasingly, openings in the education profession for such collegial leadership. Stated in slightly different language, lead learning can be characterized as a type of humble "servant leadership" (Nichols 2011).

Democratic Hermeneutics Building educators' capacities for a lead learning grounded in critical pragmatism brings me to the second major ethical challenge that I faced in creating a constructive alternative to Tyler's rationale. In thinking through my understanding of democratic values, I realized early on that I needed to work with a hermeneutic rather than an ideological orientation. In other words, I needed to treat the topic of educators' democratic ethics through an open-minded, open-hearted frame of reference (Dewey 1910/1933), which Gadamer (1975) describes as the "dialogical playfulness" that cultivates a broadening of personal horizons. Such an existential, pluralistic commitment challenges rigid, dogmatic, close-minded, and ideologically-fused interchanges where options are limited to consensus or conflict.

Bernier and Williams (1973) define ideology as "an integrated pattern of ideas, system of beliefs, or a 'group consciousness' which characterizes a social group. Such a pattern or system may include doctrines, ideals, slogans, symbols, and directions for social and political actions" (p. 27). With reference to this definition, committed ideologues are not interested in the possibilities of achieving diverse, expansive empathy and interpersonal understanding through respectful dissensus. Their focus is on scripted agreement; and if such agreement is not achievable, conflict and, perhaps, even violent confrontation may be forthcoming. Committed ideologues eschew pluralism. By definition, passionate ideologues working out of their own specific scripts talk past one another. They make no effort to understand different ideas or beliefs; they are not interested in broadening their personal horizons; they are not interested in dialogical relationships. As Garrison (1997) writes, "Monism is dogmatism" p.15). I recognized early on in my FoC action research that democratic hermeneutics is based on a generative, creative dissensus (Rancière 2010).

Based on my educational experiences as an undergraduate history major at a private liberal arts college, I recognize the importance of curriculum liberalization in fostering communities of dissensus. Abraham Lincoln — who is arguably the best of all the USA presidents and, certainly, the pivotal lead professional for democratic ethics at a critical juncture in American history - created his cabinet as a community of dissensus. Goodwin (2005) characterizes Lincoln's cabinet as a "team of rivals." Concerning Lincoln's disposition toward his political rivals, she writes,

Though Lincoln desired success as fiercely as any of his rivals, he did not allow his quest for office to consume the kindness and openheartedness with which he treated supporters and rivals alike.... With his death, Abraham Lincoln had come to seem the embodiment of his own words-"With malice toward none; with charity for all"- - voiced in his second inaugural to lay out the visionary pathway to a reconstructed union (pp. 256, 749).

Kegan (1994) defines reconstructive postmodern leaders as individuals who "challenge the unacknowledged epistemological assumptions behind modernist 
conceptions of the unilateral leader" (p. 424). Lincoln was such a postmodern leader long before such terms as modernism and postmodernism had even been coined by academics. Kegan (1994) writes, "Postmodernism suggests a kind of "conflict resolution' in which the Palestinian discovers her own Israeli-ness, the rich man discovers his poverty, the woman discovers the man inside her" (pp. 320-321). Lincoln practiced such deeply empathetic conflict resolution at the precise historical moment that his country needed such presidential leadership. With reference to democratic ethics, he was not perfect; but for his era, he was an embodiment of the USA's Declaration of Independence assertion that all humans are created equal.

Over the years, I have experimented with the introduction of the concept of curriculum liberalization in a number of ways. My current approach is to ask students to think about the critical distinction between the neo-liberal/neo-conservative control of curriculum and curriculum liberalization through the study of selected work of three curriculum scholars: Michael Apple, Wesley Null, and Joseph Schwab. Apple's (2005) critique of the emergence of "audit cultures" in educational work around the world is based on his analysis of the interplay of neo-liberal and neoconservative ideologies:

Neo-liberalism requires the constant production of evidence that you are doingthings 'efficiently' and in the 'correct' way by examining the effects on the ground of the suturing together of the seemingly contradictory tendencies of neo-liberal and neo-conservative discourses and practices.... And this is occurring at the same time as the state itself becomes increasingly subject to commercialization. This situation has given rise to what might best be called an audit culture (p. 14).

Curriculum liberalization challenges the underlying ideological assumptions of audit cultures. It is based on the recognition that all humans can build their capacities to become "free thinkers who can draw upon many fields of knowledge, pursue truth, and solve problems" (Null 2011, p. 15). Humans can be more than mindless, manipulatable consumers of capitalistic products. Null (2011) writes that curriculum liberalization "pursues the goal of liberating minds so that they can become more fully human, make rational judgments, and provide civic leadership" (p. 15). He advances this goal by inviting his readers to think through the pros and cons of five curriculum traditions (systematic, existentialist, radical, pragmatic, and deliberative) in light of Schwab's (1973) five curricular commonplaces: teachers, learners, subject matter, context and curriculum making.

I tell students that, based on my own critical thinking, I don't completely agree with either Null's or Schwab's categorization schemes, and that they are equally invited to critically question the way Null and Schwab have constructed 'curriculum.' That's what free thinkers do! They recognize that 'curriculum' is an interpretive term. However, I want them to work with Null's book because it encourages synoptic thinking. His text fosters broad deliberations informed by many different, opposing curricular perspectives. He argues that good curriculum work is not locked into a single topic, whether it's standardized testing on the political right or social justice on the political left. He writes that, "Deliberators prefers a middle path that respects wisdom and tradition but also searches for new and creative ways to solve whatever problems arise in the world of practice" (p. 261). Curriculum liberation is 
about following this Aristotelian and Deweyan middle path. Kathleen Kesson and I created a curriculum wisdom book based on this premise (Henderson and Kesson 2004), which I used in the FoC course for a couple of years.

I recognized early on in my FoC pedagogy that curriculum liberalization can be powerfully fostered through the interplay of curriculum-based reflective inquiry and deliberative conversation. Collaborating with four colleagues, I created a book that addressed this interplay (Henderson 1992); and due to my own ongoing trailand-error learning in the FoC course, I continued to revise my conceptions of this interplay through two completely revised editions of the original 1992 text. As Dewey (1910/1933) argues and clearly illustrates in his seminal text on thinking, humans break dysfunctional and/or limiting habits and customs through reflective inquiry - through a continuous and recursive consideration of the consequences of their actions in a context of humble, open-minded questioning. In a similar vein, Schwab (1978) argues that curriculum work at its best requires a commitment to deliberation that is grounded in practical and eclectic arts; and parallel to both Dewey's and Schwab's arguments, Pinar et al. (1995) provide a comprehensive overview of understanding "curriculum as complicated conversation." As I refined my feel for democratic hermeneutics as a key ethical touchstone, I continued to delve into this interplay between curricular reflective inquiry (RI) and deliberative conversation (DC).

This conjunction of Dewey's, Schwab's, and Pinar's work—along with its vast related literature-became a key referent for my $\mathrm{FoC}$ action research. I was increasingly committed to explicating and clarifying curriculum-based RI/DC. My most recent collaborative text on the reconceptualization of curriculum development, which I have already introduced, advances a lead-learning study agenda of three RIs informed by four DCs. I introduce this agenda as follows:

\footnotetext{
Section I [of this book] is an open-ended arrangement of three interrelated reflective inquiries informed by four deliberative conversations. To quickly review, the reflective inquiries address the interrelated questions of how to teach for $3 \mathrm{~S}$ understanding, how to embody $3 \mathrm{~S}$ understanding, and how to build collegial and public trust for 3S pedagogy; while the four deliberative conversations are organized around the topics of management-to-wisdom critique/negotiation, social justice, democratic humanism, and mythopoetic inspiration. Over the course of six years of action research, this particular configuration of topics has emerged as a powerful way to introduce and sustain the collegial study and practice of $3 \mathrm{~S}$ pedagogy. In short, chapters two through eight are single-authored essays that function as an ensemble of lead-learning invitations... (Henderson et al. 2015, p. 35)
}

Holistic Pedagogy Through my continuing explorations of the ethics of democratic hermeneutics, I realized that the artistry of holistic pedagogy is another key ethical end-in-view. I've already introduced the notion of $3 \mathrm{~S}$ pedagogy. As I experimented with ways of introducing this pedagogical artistry, I became increasingly aware that this conception of teaching is informed by the European, particularly German Bildung/Didaktik heritage as summarized by Autio (2009), "Bildung can be understood as a kind of self-formation along the lines of a wider [societal] belonging and...Didaktik refers generally to the pedagogical techniques for intertwining if not spiraling subjectivity and society together" (p. 71). 
However, I approached this Bildung/Didaktik heritage with a certain Deweyan caution. Given my commitment to democratic hermeneutics, I didn't want to get caught up in Hegel's rational systemization, and I am indebted to Good's (2006) nuanced explanation of how Dewey established a constructive critical distance from Hegel's philosophy. Good's thesis is that Dewey advanced an American Bildung tradition that drew on Hegel's key concept of Aufheben, translated as sublation, without getting lost in Hegel's quasi-religious dogmatism-Hegel's pretense that, through his dialectical rationalism, he had achieved the proper overview of the mysteries of life. Good (2006) writes:

The American Bildung tradition is based upon an inherently expansive conception of philosophy because it requires its practitioners to be broadly educated, across academic disciplines, to better understand their society's ideals, practices, and institutions. Moreover, it demands that philosophers keep one foot firmly planted in their social and historical context and one in their study. More theoretically, the American Bildung tradition rejects mechanistic, static views of reality in favor of an organic and historical model according to which individual persons and objects are interrelated within a dynamic process. Rather than assume the Cartesian notion that knowledge is gained by reducing complex wholes to their constituent parts, the Bildung tradition maintains that knowledge of the part comes from attending to the ways it is related to other parts and the way it functions within the larger whole. ...The most significant Hegelian deposit in Dewey's mature thought is the Bildung model of philosophy. I hasten to concede, however, that Dewey rejected Hegel's systematic efforts... (pp. xx-xxi).

I quote Good at length for a particular reason. I wasn't interested in summarily rejecting Tyler's rationale, I simply wanted to sublate it. Good (2006) explains: "The dialectic, Hegel's perception of scientific method, always begins with a hypothesis in that it is always a position that is asserted provisionally, adapted, developed, and ultimately sublated (Aufheben), that is, incorporated without being eliminated, into a more inclusive understanding of the subject matter" (p.13).

Good's reference to an American Bildung tradition, initiated by Dewey and then refined in subsequent generations of educators, was articulated in the United States as the curriculum concept of democratic general education. Tanner and Tanner (2007) provide a thorough overview of the American heritage of this concept. They begin their book by noting that this democratic, holistic orientation can be traced back to Thomas Jefferson's views on the importance of education in a freedomloving society. They quote Jefferson, "If a nation expects to be ignorant and free in a state of civilization, it expects what never was and never will be" (Lee 1961, pp. 18-19). They then cite Lawrence Cremin's insight that "the entire course of American educational history is based on the gradual realization of the Jeffersonian ideal" (Cremin 1965, p. 40). In the context of a thorough historical analysis of the views of hundreds of American educational leaders in the nineteenth and twentieth centuries on the importance of a democratic, holistic approach to curriculum work, Tanner and Tanner (2007) write:

No document of the twentieth century was more influential in shaping the structure and function of the American educational system than the report of the NEA [National Education Association] Commission on the Reorganization of Secondary Education, Cardinal Principles of Secondary Education (1918)....Embracing Dewey's [1916] concept of social 
efficiency in a democracy..., in sharp contrast to social efficiency in undemocratic societies, the Cardinal Principles report called for the fullest release of human potential through the widest extension of educational opportunity (pp. 280-281).

In the FoC course, I point out to students that this historic commitment to democratic general education with its implications for practicing the artistry of holistic pedagogy is under attack from ideologues on the right and the left. With reference to the ideological right, I ask them to think about Ylimaki's (2011) critical analysis of the ways in which a hegemonic "conservative modernization"-involving the synergy between neoliberalism, neoconservatism, authoritarian populism, and public management policy and the social dynamics of an emerging managerial middle class - has resulted in the narrowing of the curriculum. With reference to the ideological left, I ask them to think about the fact that I am teaching them the fundamentals of curriculum as a holistic public intellectual, not as a narrow critical specialist (Henderson and Kesson 2001). Since academic cultures generally have a leftist orientation and since graduate students have a certain amount of curricular experience with such cultures, I ask them to ponder why more professors aren't working as public intellectuals? I also ask them if they feel they received a broad liberal arts education as an undergraduate. If not, why not? If they went through a preservice teacher education program, were they encouraged to think and act like holistic teachers committed to democratic general education; and if not, why not? Were they encouraged to think of themselves as lead professionals for democratic ethics?

I want to conclude my pedagogical narrative with a concise overview of the FoC design that has gradually emerged over 25 years of action research. The course is currently organized around the aim of building educators' capacities to work as lead professionals for democratic ethics, as guided by three thematic orientations that are advanced through the disciplined study of nine curriculum concepts: curriculum criticism, transformative curriculum leadership, curriculum-as-currere, $3 \mathrm{~S}$ pedagogy, curriculum liberalization, lead learning, curriculum-based reflective inquiry, curriculum-based deliberative conversation, and democratic general education. The focus of our collaborative chapter now turns to a discussion of the interrelated conceptions of teacher leadership and administrative leadership that emerge out of this approach to understanding the fundamentals of curriculum.

Teachers as Leaders Jim Henderson's narrative of theorizing curriculum leadership is one that unsettles polemic voices in the contemporary cultural milieu of educational study and practice. The fluidity of his 25-year narrative cuts diagonally across stable ideologies put forth both from the right and the left in the United States. From the right, a consistent and dominant commitment to technical rationality has maintained and promulgated key concepts of efficiency and development. Such trends were initiated at the very beginning of North American curriculum studies by Franklin Bobbitt, later refined by Ralph Tyler and are presently reified through the alignment of standards-based instruction scope and sequence charts and standardized test accountability. From the left, progressives have promulgated diverse epistemologies centering around two key concepts, social reproduction and political resistance (Pinar 2013). Following Schwab's declaration in 1969 that North 
American curriculum studies had become moribund, re-conceptualizers of curriculum have for decades turned their attention from development to understanding (Pinar et al. 1995). Henderson conceptualizes a middle way for curriculum workers and invites graduates students in FoC to consider in the possibilities for thinking, speaking and activating their own middle way ventures.

Though recently articulated as an alternative to the Tyler rationale, the nonideological have been a sustained feature of Henderson's scholarly trajectory. For example, when Wraga's (1999) and Pinar's (1999) contrasting ideas regarding the proper purposes and directions of contemporary curriculum scholarship were brought to bear on the pages of Educational Researcher, Henderson (2001b) interceded with an argument for an alternative that appreciated both tradition and the avant-garde. Understanding curriculum development as a circuit of problem-solving raises the very important and practical question of "Is this working?" However, understanding curriculum as an extraordinarily complicated conversation (Pinar et al. 1995) advances critical and useful questions regarding "what is implicated when one claims something is or isn't working?" The reconceptualization teaches us that matters of identity, power and language are always central and that curriculum is never apolitical or ahistorical. For Henderson (2001b), these are supplemental and not competing questions. His sustained dissatisfaction with either/or thinking was salient feature of the theorizing that eventually lead to Re-conceptualizing Curriculum Development (Henderson et al. 2015).

Limitations of space will not allow for a thorough examination of the impact of Jim's work as it has been experienced by diverse graduate students over the years. However, the pages that follow I (Dan) will write as a "teacher leader", who has been experiencing FoC, since 2008. I first engaged became engaged with Jim's work as a public school kindergarten teacher and doctoral student. Seized by both the content and method of the course, I remained interested in FoC as a teaching assistant, one of Jim's doctoral advisees and now as a teacher educator in another state. Therefore, my applications of the Henderson rationale are situated within my experiences as a teacher of young children, an emerging curriculum scholar and a teacher educator. In each of these capacities, I continue to draw on the ideas that Jim outlined above in a humble attempt to live out an Aristotelian telos of curriculum work and to keep going when reality makes it all too obvious that I have come up short. The two interrelated aspects of the Henderson rationale that I will emphasize in regards to how they apply to "curriculum-based teacher leadership" are: (1) the charitable listening and love of wisdom inherent to a commitment to finding a middle way; and, (2) the pedagogical roots of his curriculum theorizing that invokes one to walk their talk. Fusing these two attributes, I will argue constitutes something similar to what Kyla Ebels-Dugan's (2015) conceives of as "tenacious intellectual virtues", a quality that we must embody before we can ignite it in others. 


\section{Finding a Middle Way}

As mentioned above, I was introduced to curriculum theory in Jim's FoC course in 2008 working as a kindergarten teacher and beginning doctoral studies. I began my teaching career in 2000, shortly before the passage of the No Child Left Behind Act (NCLB). Therefore, my life as a teacher could be accurately described as taking place in the accountability era. Like so many teachers, I began my career with a vision of the teacher that I endeavored to be. It wasn't long until, I faced the common reality that my vision was at odds with the dominant culture of curriculum at my school. Enacting my ideals of being a caring and inclusive teacher of young children was a daunting enough challenge, which seemed to become increasingly thwarted the more dominant discourse-practices took hold. The rhetoric of neoliberal reformed seemed to at best trivialize and at worst distort the concrete realities of 5-year-olds with abstractions of preparing 'college and career readiness' that will prime them to 'compete in the 21 st century global marketplace.' Hence, I came to doctoral studies and to curriculum theory coping with a growing disconnect between the teacher I aspired to be and the contextualizing culture of curriculum that defined what was 'good.' This is a common, but nonetheless frustrating and even painful existential reality of many contemporary teachers. Speaking of her own experience, distinguished theorist, bell hooks (1994) powerfully testifies,

I came to theory because I was hurting- the pain within me was so intense that I could not go on living. I came to theory desperate, wanting to comprehend- to grasp what was happening around and within me. Most importantly, I wanted to make the hurt go away. I saw in theory then a location for healing (p.59).

The eloquent words of bell hooks continue to resonate with me, although in a very different way now than when I first read them. With an embarrassing amount of naiveté, I came to curriculum theory because I was morally outraged. The frustrations that I had experienced were so penetrating that I was ready for political resistance. I came to curriculum theory with a heightened sense of criticality wanting to accumulate knowledge for resistance- to understand the system and my capacity to disobey. Mostly, I wanted to win. I saw in theory the tools for formulating the right argument. For my first assignment in FoC, I wrote a scathing critique of a common system of instructional management. I chastised the hubris of scholars who either didn't understand or appreciate the value of inquiry-based pedagogy and the complexities of fostering a caring and cooperative classroom community. While honoring the sincerity of my concerns, Jim challenged me to reconsider the hubris in my own analysis, suggesting that I think about how I might engage in a collegial conversation by raising a good question, instead of asserting a strong opinion. A lead professional is a colleague who engages with peers to influence and be open to being influenced. I could no longer take solace in shutting my classroom door and comfortably conceding that my best work would be an uncover mission. In other words, Jim led me to search for a middle way. My options needn't be restricted to bureaucrat or dissident. A middle way of curriculum-based teacher leadership was indeed conceivable. 
The middle way of curriculum-based teacher leadership is methodologically speaking the enactment of critical bricolage enabling one to "make use of positive contributions of disciplines while avoiding disciplinary parochialism and domination" (Kincheloe 2001, p. 684). William Pinar (2006) suggests that disciplined study can indeed transform curriculum practice. Yet, Henderson and Gornik (2007) supplement such a commitment to study-based complicated conversation with an acknowledgement of the historical and systematic dominance of technical procedural rationality in curriculum practice. Underscoring the paradigmatic shifts, which are made evident in the complicated conversations among re-conceptualizers of curriculum, keeps theory grounded in pedagogical practice and away from tendencies to "become abstractions split-off from the concrete complexity of the historical moment" (Pinar 2013, p.7). Efforts to shed light upon matters of power, identity and discourse associated with the dominant paradigm, according to Pinar (2013), are intellectually exhausted. Moreover, when confined to "safe intellectual spaces for theorizing" complicated conversations remain detached from the public sphere, which continues on with the standardized management of curriculum. As a middle way, the Henderson rationale issues a provocative and inclusive invitation to all curriculum workers to consider the possibilities to think, speak and act as lead professionals for democratic ethics.

Many students in FoC spend the first several weeks of the course experiencing cognitive dissonance. This is to be expected, since apprehending curriculum as a complicated conversation represents a paradigm shift that requires many individuals to critically question taken for granted aspects of their daily practices. In other words, for many teachers finding a middle way involves fostering a critical relationship with inculcated assumptions. Such a paradigm shift includes a process of re-orienting oneself to habituated modes of understanding with a heightened level of critical awareness. Other students, such as myself, enter FoC already critical of the dominant discourse-practices. As indicated in the example above, the form of criticality that compelled me toward doctoral studies had its own, albeit very different, limitations. Overconfident in my own critical acumen, I lodged unforgiving negative critiques of authoritative structures without affirming any of their amenable qualities. Denouncing the status quo without advancing an alternative way of proceeding with educational problem solving, I was transmitting monolithic critical ideas of my own and failing to offer a transformative argument. Ebels-Dugan (2015) conceptualizes humility regarding one's own critical judgements and charity toward others' perspectives are the intellectual virtues central to cultivating autonomy. Hence, these intellectual virtues are key components to curriculum-based teacher leadership.

\section{Pedagogical Roots}

The second key component of curriculum-based teacher leadership to be highlighted in this chapter is that it is rooted in pedagogical practice. Neoliberal educational reform allied with accountability systems that are carried out by the audits of uncritical middle-managers who embrace "new professional identities" is a 
dominant force in P-20 educational institutions. An incredibly important aspect of Jim's evolving theorizing and scholarly voice narrated above, is that it is inseparable from the practical realities that comprised his 25 -year journey of teaching. Kincheloe et al. (2011) demand, "teachers must have more voice and more respect in the culture of education... [and] must join the culture of researchers if a new level of educational rigor and quality is ever to be achieved" (p.165). Conversely, to generate new possibilities of rigor and quality Henderson's narrative of action research and theorizing joins the culture of teachers. This is more than a matter of semantics. The eruditions of democratic curriculum-based pedagogy, as they are conceptualized in Jim's opening narrative and introduced to graduate students in FoC are more than theoretical abstractions. Rather, academic study was the means to inspire and inform a re-thinking, re-articulating and a re-working of one's curriculum practice. Furthermore, one's curriculum practice was the impetus for academic study. The Henderson rationale and the lead-learning invitations that have been extended over the years in $\mathrm{FoC}$ not only conceptualize but embody the normative ethical referents critical pragmatism, democratic hermeneutics and holistic pedagogy.

In my professional journey, the initial and immediate outcome of Jim's leadlearning invitation was that I was no longer content to shut my door and secretly do things my way. I encountered a new sense of responsibility to extend my sphere of influence by leaving my classroom door and an invitation for dialogue open. The particulars of my journey as a kindergarten teacher had the general implication of my following Jim's lead in thinking and talking about how curriculum studies can be the basis for the practice of a democratic ethic of teacher leadership. Alongside the theoretical eclecticism in the opening section of this chapter, I would like to bring attention to the concretized example of Jim's pedagogical practice. The process of replacing the Tyler rationale with a commitment to democratic, curriculumbased pedagogy, necessarily involved the careful and sustained narratives of a supreme artist, a reflective teacher engaged in disciplined academic study. This is the conceptual and operational definition of teacher leadership that guided my efforts as kindergarten teacher and emerging educational researcher.

Now I find myself working with graduate students working to earn Masters of Arts in education with teacher leadership endorsement. At the beginning of a course that I teach, my students read York-Barr and Duke's (2004) comprehensive review of two decades of research literature on the topic of teacher leadership. My students did not enjoy the reading assignment and offered two main criticisms. First, they found the technical procedures in the extant literature to be mostly comprised of strategies that are generally known among experienced educators. In this way, they complain, the authors' 62 pages offer them nothing new. Secondly, some students express exasperation with the forthright admission in the abstract that "the construct of teacher leadership is not well defined, conceptually or operationally" (York-Barr and Duke 2004, p. 255). They query how teacher leadership can be gaining political momentum nationally and among many state departments without a definition. Further, they wonder if this lack of a definition puts their program on a very unstable foundation. 
In search of clarity, we turn to our state department's website only to find wording that implicitly divides teachers and leaders into two separate groups. As the scrutiny intensifies, it is brought to bear that most of the rhetoric on innovation in schools is comprised of benign, commonplace catchphrases and slogans. Our state department provides a concise definition on a document titled the Kentucky Teacher Leadership Framework, "Teacher leaders transform their classrooms, schools, and profession, activating teacher growth and achieving equity and excellence for students" (Kentucky Teacher Leadership Work Team 2015). Eyes begin to roll as we unpack this simplistic sentence that vaguely charges my students with responsibilities to transform their context, galvanize imprecise growth among their colleagues, and achieve unprecedented equity for students. However, the faithful commitments of dedicated teachers persist in this conversation. After all, they do indeed endeavor to improve their schools, refine their teaching and do so to enhance student outcomes. They are not opposed to innovation. Yet, the surveillance of walk-through observations and the auditing of routine progress monitoring tests leave them little time and space to lead innovations.

Any mention of curriculum theory is absent from York-Barr and Duke's (2004) review of what is known about teacher leadership. Thus, at first glance, it seems as though using curriculum studies as the basis for apprehending and practicing teacher leadership is an idea the authors did not think to consider. Indeed, scholarship such as Ylimaki's (2011) fusing of the fields of educational administration and curriculum theory are unique and provide an imperative update to York-Barr and Duke's (2004) review. After all, if influential proprietary organizations, state departments and graduate programs are going to encourage teachers to lead it is reasonable to contemplate what is unique about the prospect of teachers leading as opposed to leadership from policy makers, school administrators or educational researchers. I challenge my students to consider how they are, as teachers, are uniquely situated so they can accomplish ends out of the reach of stakeholders with more traditional and formal authority. For these reasons alone as case is made for curriculum-based teacher leadership, since curriculum and pedagogy are the central facets of teachers' personalized and contextualized daily work.

However, I share with my students a second critique of the mainstream literature on teacher leadership. Reflecting upon the obvious absence of explicit reference to curriculum theory that is customary in mainstream literature, we take into account the conventions of curriculum theory implicitly infused throughout the review. In a laudable effort to make sense out of the extant literature, York-Barr and Duke (2004) begin with an apolitical, value-neutral conceptual definition that is too vague to strike controversy: "we suggest that teacher leadership is the process by which teachers, individually or collectively, influence their colleagues, principals, and other members of school communities to improve teaching and learning practices with the aim of increased student learning and achievement" (pp. 287-288). No reasonable person would object to teachers influencing improvements to bolster learning. However, my students cannot help but laugh how insights garnered from a comprehensive review of two decades of research can be deduced into the benign statement of "do and promote good things, so students will learn better". Is it 
possible that 20 years of research on teacher leadership has resulted in benign rhetoric without a substantive direction for prospective teacher leaders?

Perhaps this sort of conceptual emptiness did not sit well with the authors, because they persisted in operationalizing their loose conceptualization of teacher leadership. In doing so, they reveal how the predominance of technical rationale curriculum theory ensues as either a non-reflective or unacknowledged feature prevailing teacher leader discourse-practices. Tacitly utilizing each of Tyler's (1949) four fundamentals of curriculum development, York-Barr and Duke (2004) customarily begin the process of teacher leadership with "schools and districts must clearly articulate student learning and school improvement goals" (p. 290). Once these goals have defined the "purpose" of teacher leadership, the "possible ways in which teachers can lead efforts related to goal accomplishment must be generated" (p. 290). In Tyler's terms, this marks how teachers will experience opportunities to lead initiatives they may or may not have taken part in articulating. York-Barr and Duke (2004) suggest such experiences must be guided by the recognition that "unique and varied leadership capacities of individual teachers must be matched with unique and varied leadership functions..., [along with structures that] communicate purposes and expectations with staff..., [provide] school supports, [and] clear indicators of progress" (pp. 290-291). It is not insignificant to note that these purposes, experiential opportunities, organizational structures and evaluative systems of teacher leadership are developed at the systems level and may or may not include the personalized and contextualized perspectives of classroom teachers. Therefore, nowhere is it assumed that the development of teacher leadership is or ought to be led by classroom teachers.

Justifiably, my students are dissatisfied with the prospect of playing an ambiguous role in nebulously conceived teacher leadership. Why pursue teacher leadership if doesn't necessarily include an appreciation of teachers' intellectual autonomy and professional decision-making capacity? If curriculum and teaching are apprehended by these procedural mechanisms, then corresponding "new professional identities" will characterize dominant images of leadership (Ylimaki 2011). In plain terms, this puts teacher leadership on a trajectory of becoming an unappealing potential for teachers to be recruited as cost-efficient assistants to building principals in the carrying out middle-management accountability audits. The Henderson rationale offers an alternative and more complicated course. Recognizing the probable persistence of technical rationality, a democratic ethic of curriculum-based teacher leadership begins with an immanent break. Breaking from the taken for granted assumption of the dominant paradigm does not free a teacher leader from the practical constraints of instructional management. However, bringing curriculum theory into the reflective experience of teacher leadership sheds light on the habituated intellectual structures that are engrained in our dominant culture of curriculum. Curriculum-based teacher leadership is ignited with an event of becoming critically aware that "one of the most salient features of our culture is that there is so much bullshit" (Frankfurt 2005, p. 1).

Frankfurt's (2005) thesis is not that the bullshit is rooted in malicious deceptions or untruths. Rather, it is a product of lack of regard for the truth altogether. The truth is that curriculum and pedagogy are value-laden practices and value judgements are 
inscribed in all educational activities (Buzzelli and Johnston 2002; Hansen 2001). The imprecise rhetoric of "improving teaching" and "increasing learning" enable the neoliberal interests that drive educational policy, discourse and practice to be an elusive quality of the curriculum. To be certain, standardized systems of instructional management audit performativity without attending to the underlying ethics of curriculum practices. Therefore, one can make a career as a teacher, researcher or leader by way of bureaucratic functioning. Curriculum-based teacher leadership makes an alternative way available for educators who are committed to teaching and leading as a professional who "take an ethical stance in the world" (Block 2008, p. 416).

The chief distinctions between the technical way that teacher leadership is most prevalently being operationalized and Henderson's adaptive curriculum-based teacher leadership are the implicated ways for educators' being and becoming in the world. Dominant discourse-practices offer a way of deferring to intellectual authorities and complying with protocol to efficiently and effectively work toward the unacknowledged values of clandestine hegemonic sources. The Henderson rationale, on the other hand, challenges teacher leaders to think, speak and act in ways that work toward their becoming lead professionals for a democratic vision. Bringing a commitment to democratic ways of living with the normative referents of three broad themes to the fore, ventures of teacher leadership are more holistically conceptualized as encompassing personalized and contextualized journey of understanding. It might be said that the greatest irony of the accountability culture is that no one is held accountable for the value judgements inherent to any and all educational decisions.

Opting for a road less traveled, the efforts of teacher leaders who take an ethical stance in the world will often not be recognized or encouraged. Even more seldom will these efforts be commended. Hence, according to Kyla Ebels-Dugan (2015) intellectual virtues of humility and charity must be supplemented with tenacity. Her aims toward intellectual autonomy parallel Henderson's advancement of free thinking. What is more, her conceptualization of tenacity brings to bear the bureaucratic realities of P-20 teachers' situational contexts. Routinely expected and often directed to carry our bureaucratic functions, thinking as consumers and transmitters of knowledge pre-established by centralized authorities is indeed, for teachers, the path of least resistance. Hence, the research and policy on teacher leadership confine teachers' discourse-practices to the facilitation of technical conversations. Drawing upon his own experiential learning, as a free-thinking teacher, Henderson maps an alternate for teacher leaders. Imploring curriculum workers to think for themselves, as participants in an extraordinary complicated conversation, broad democratic ends-in-view emerging, powerful ethical communities can be affirmed on this road less taken. Therefore, the Henderson rationale invites teachers' discourse and practices to humbly inquire and charitably deliberate, while tenaciously engaging in transformative conversations.

Along the alternative route, democratic ethical norms fill the empty conceptual vessel within which veiled hegemonic interests operate through alleged value neutrality. In the spirit of Lincoln's "charity for all," as cited earlier in this chapter, it is important to recognize the contribution of Ralph Tyler. His linear circuit for 
curriculum problem solving has engrained habits of technical reflection into cultures of curriculum. This is his imperishable legacy of which bricoleurs make use, while circumventing the disciplinary narrowness that was likely not intended or even perceived in 1949. Benefitting from the reconceptualization studies, it is not too bold for us to supplement Tyler's technical rationale with a reflective "circuit of valuation" (Ryan 2011). In doing so, we are simply asserting that any set of beliefs, images and values are as good as any other. Though Tyler may have passively alluded to his progressive preferences, regarding ethics he only insisted upon an empty conceptual vessel, the creation of a philosophical screen. Since technical efficiency is equally well suited for any ethical or political orientation, curriculumbased teacher leaders do well to raise questions regarding how democratic virtues are made evident in educational enterprises.

Teaching is an innately moral endeavor (Buzzelli and Johnston 2002; Hansen 2001). How the value judgments that are inevitably infused in daily practice are incorporated into curriculum problem solving is where Tyler was flexible to the point of being relativistic and we are unwavering. Critical pragmatism, democratic hermeneutics and holistic pedagogy are the broad normative referents that constitute an open set of interpretations. However, they also demarcate an assertive boundary of what constitutes quality curriculum work in a democratic society. Not any philosophical screen is suitable for developing a curriculum in a free and just society. By merely stipulating that a philosophical screen be established, the Tyler rationale enjoys the same utility in an oppressive autocracy as a liberal democracy. While technical aspects of teacher leadership remain important, they are inept for ethically grounding teacher leadership.

Grounded in democratic ethics, I invite my students to think, discuss and act upon possibilities for curriculum-based teacher leadership that operate through adaptive, instead of technical fundamentals of curriculum. I ask them to consider transformative educational ends in view, instead of transmitting knowledge sanctioned by learning standards. Indeed, in my courses they are unsuspectingly invited to turn engage in an alternative discourse about their practices. They may discuss what is possible and what they find preferable, against the grains of data-driven standardization. They are encouraged to exercise and foster intellectual autonomy, while considering what is good for all. They are reminded that curriculum-based teacher leadership is deeply personal, historical, contextualized by the perspectives of diverse stakeholders and evolving through ongoing inquiry. We engage in holistic "aims talking" (Noddings 2013) that serve as ends-in-view for 3S pedagogy. Moreover, we proceed with a humble love of wisdom, and charity for all and a tenacious sense of commitment, as we know that leading this form professional artistry runs against the grain of dominant cultures of curriculum. This is how the adaptive fundamentals of curriculum highlighted in Jim's opening narrative are concretely operationalized in my classroom. Next, we will turn to how this work can be systemically supported. 


\section{The Interplay of Administrative and Teacher Leadership}

If we assume that schools will be organized within a refined and constructive alternative to Tyler's (1949) rationale; and if we assume that one aim will be to build educators' capacities to work as lead professionals for democratic ethics, as guided by three thematic orientations advanced through the disciplined study of nine curriculum concepts; and if we assume that teachers will flourish as democratic visionaries, colleagues, and artists through disciplined study and practice embodying the personal journeys that this work entails; then it stands to reason that the same three broad ethical themes that guide curriculum development and teacher leadership, must also guide the definition and operational aspects of administrative leadership and policy development. Just as Tyler's rationale is still considered the paradigmatic exemplar for conceptions of curriculum development (Null 2008; Walker and Soltis 2009), we critically recognize that the Standards for Advanced Programs in Educational Leadership for principals, superintendents, curriculum directors and supervisors, and policy "actions of government and the intentions that determine those actions" (Cochran et al. 1986, p. 2) do not advance a deep critical awareness of educational leadership and policy purposes.

Leadership Standards The common themes in the leadership standards represent what is known about current practice with an emphasis on the importance of a focus on student achievement; data-based decision making; communication and collaboration; shared leadership; instructional leadership and continuous professional development. One reason for the almost universal buy-in of this definition of leadership in schools, districts, communities, universities, and state and national government is its seductive rationality. Not unlike Tyler's rationale, these leadership standards do not advance a deep critical awareness of leadership purposes and therefore do not support critical pragmatism. Such a pattern or system is not interested in possibilities of achieving diverse, expansive understanding, but more focused on scripted agreement, and as such do not support educators' democratic hermeneutics through an open-minded, open-hearted frame of reference. Further, an educator operating out of holistic pedagogy would not find support in these standards to lead for the fullest release of human potential through the widest extension of educational opportunity.

\section{Public Policy}

Public policy is adopted by an agency of the government and is generally a principled guide for administrators to follow in carrying out their responsibilities" (Kowalski 2013, p. 163). In simple terms, the process of policy making is focused on establishing parameters about what should be done, and the constraints about what cannot be done in a school district. Schwartz and Sharpe (2010) remind us that we as human beings use two tools to manage organizational behavior: (1) rules and administrative oversight, and (2) incentives that encourage good performance by rewarding people for it. According to Kowalski (2013) properly constructed policy (rules) is a process that must consider four variables: legal, political, philosophical and professional. As such, we as lead professionals for democratic ethics find ourselves in a bind because while "good rules might be useful as guides as we 
try to manage multiple aims (legal, political, philosophical and professional), they will never be subtle enough and nuanced enough to apply in every situation (Schwartz and Sharpe 2010, p.7).

We posit for all societies with democratic ideals and aspirations, that at the policy level, educators be regarded as visionaries and trustworthy professionals capable of informed ethical judgments based on disciplined study and practice with a more hermeneutic rather than ideological orientation. More theoretically, as Jim Henderson asserts above, we reject the mechanistic, static views of reality in favor of an organic and historical model according to which individual persons and objects are interrelated within a dynamic process.

Administrative Leadership Defined With 41 years of experience as administrators in K-12, we contribute to this chapter with full empathy for the plight of administrators in this field today. We are not so far removed to pompously presume that by simply reading this section, full absorption of these theory-based suggestions will be incorporated into an already overloaded and demanding agenda. We are certainly aware of the many standardized requirements that administrators in the United States must perform on a regular basis, many of which leave us feeling disconnected from the very reason we chose this profession in the first place. We believe that 'good' curriculum work as indicated above, as the study and practice of the relationship between educational courses of action and democratic living, stirs and awakens a vital and missing link for educators living in societies with democratic ideals. As administrative leaders in education, we encourage you to imagine the moral possibilities that may be latent in your leadership repertoire and seek, as Jim Henderson refers to, a middle ground that begins with "reconceptualizing received standards and cultivating reflective inquiry" (Henderson and Gornik 2007, p. 93). We invite you to avoid meeting only the leadership requirements of neoliberal standardization (Watkins 2012) which causes our moral skills to be "chipped away by an over reliance on rules and procedures that deprive us of the opportunity to improvise" (Schwartz and Sharpe 2010, p. 111) and begin to imagine a cross-paradigm approach of standardized management and curriculum wisdom (Samford 2015). This work is invitational and hopeful. We invite you to join us in our quest for a better way by beginning the deliberative and complicated conversation this view of democratic administrative leadership embraces.

From a systems thinking point of view, if curriculum development is now being influenced by this open set of ethical themes, which allows for the play of diversified interpretations characteristic of democratic deliberations, then the culture needed to support this work will be central to its success. Within this culture, administrators committed to work as democratic visionaries, colleagues, and artists through disciplined study and practice while embodying a personal journey will simultaneously work to create a culture of support for teacher leaders working to do the same (Gornik and Samford, in press). These are two very distinct paths, which will be addressed in this section of the chapter. Administrative leaders are both lead learners and critical colleagues, supporting and nurturing while learning and 
growing all the while creating this same environment in their building or district for the teacher leaders to embark upon their own journey of understanding.

It is our contention that growth-minded leaders "start with a belief in human potential and development-both their own and other people's" (Dweck 2008, p. 125), so the focus becomes development and creation rather than answers and agreement. If we are seeking the kind of change, we must seek renewal (Sirotnik 1999) where every person is a contributor to improve our practice in a truly democratic forum (Nancy 2010); where all participants work toward a goal with a deep respect for the value that each person brings to the table. This culture of change is not possible in a district without the support of the administrative leader: "Conditions must be deliberately created to enable the mass of people to act on their power to choose" (Greene 1988).

Creating a Culture of Support Teacher leadership is not new. For over 25 years, Jim Henderson has been advancing democratically-inspired teaching and learning that uses deep subject matter understanding as a pathway to deeper understanding of the self and the society, or what he refers to as $3 \mathrm{~S}$ education. Teacher leaders can and will lead beyond the classroom using the $3 \mathrm{~S}$ design but without the support of the administration, efforts are stalled and energies frustrated. As Kegan so plainly states "a program can fail to provide the necessary evolutionary support by neglecting to build a bridge out of and beyond the old world" (1994, p. 46).

Our research is beginning to suggest that the prevailing conception of teacher leadership is not reaching beyond the individual classrooms. In other words, teachers are returning to their classrooms eager to utilize $3 \mathrm{~S}$ concepts in their classrooms but are unable to collaboratively share these practices with their colleagues because the basic infrastructure in most schools does not support this kind of ethical imaginings. If administrators are expected to provide this support for teacher leaders, they too need professional learning opportunities that empower them to embark upon their own journey of understanding. Due to the fact that current leadership standards do not define leaders as democratic visionaries, colleagues, and artists engaging with teachers in disciplined study, we propose working with administrative leaders to address these missing yet vital variables. Theoretically and pragmatically, we propose working with administrators to support a culture that "elicits administrative support to make time to develop trust thus promoting collegiality that expects sustained change grounded in democratic values to support curriculum development" (Samford 2016, p. 81).

Unfortunately, this is not the norm in administrative leadership in the United States today. The ideology that permeates our institutions of education not only discourages but prohibits a generative forum for multiple reasons, one of which is a lack of time dedicated to support such complicated conversation. There is barely enough time built into professional learning for maintenance of the banking concept of "container" to be "filled" (Freire 1997, p. 53) let alone the possibility that deep conversation may lead to questioning or even productive conflict. As a result, professional learning in an educational setting focuses primarily on "scripted agreement" painfully avoiding the "possibilities of achieving diverse, expansive empathy 
and understanding through respectful dissensus" as Jim Henderson suggests. We know that it takes time to develop the trust needed to support sustaining change in this level of curriculum development.

Taking Time to Develop Trust Apple notes there is blatant "loss of time to keep up with one's field" (Apple 2004, p. 189) and describes the "deskilling" of those in the field of education as "cut off from their own fields and again must rely even more heavily on ideas and processes provided by "experts" (p. 189). Time to develop trust so that all contributing educators have the opportunity to share curriculum-based deliberative conversations is imperative in creating a culture of support. As one teacher leader explains, "Trust is of the utmost significance in widening the possibilities of collegiality, of creative collaboration, and of expanding new horizons. The potential for growth is exponential when trust is established" (Griest et al. 2015, p. 161). In Finland, they know the value of taking time to cultivate trust. According to Sahlberg (2011), "Basic to this new culture has been the cultivation of trust between education authorities and schools. Such trust, as we have witnessed, makes reform that is not only sustainable but also owned by the teachers who implement it" (p. 2). Establishing this level of trust takes time, yet is imperative in sustaining change.

Sustaining Change to Support Curriculum Development We refer to Frank Ryan's (2011) interpretation of Dewey and Bentley' (1949) transactional "circuit of inquiry" to illustrate the change that both administrators and teacher leaders may undergo in sustaining a change in curriculum. In Ryan's interpretation, a nonreflective experience is interrupted by a problem. If the problem can be solved by habit, we return to a nonreflective state. However, if the problem is too big, we move forward to create a hypothesis and gather the tools and data to conduct an experiment. The object is to return to state of nonreflective experience, but not the same experience, we have changed. The nonreflective state is not the same but a new, changed nonreflective state. Interpreted, we must first realize that the problem of neoliberalism in education is too big to revert back to our habitual standardized management paradigm. We must move forward with a new hypothesis consisting of multiple theories and practical implementation to sustain a new nonreflective state. We look to Schwab's (1978) eclectic approach of curriculum theory by recognizing weaknesses of some theories while we seek to embrace that other theories may "provide some degree of repair of these weaknesses" (p. 295). Currently, we have embarked upon a journey to support administrators on their eclectic path of creating a culture to support their own journey and that of the teacher leaders.

The Research Award In spring of 2015, Rosemary Gornik received sizable award from the Ohio Department of Education to conduct research on improving teacher quality through teacher leadership. She formed a support team and together, we began to formulate the agenda for a 3-year journey to implement and support teacher leadership in two districts, one urban and one suburban. Our mission, to expose teachers and administrators to a definition of teacher leadership that embraces the three normative themes and nine concepts mentioned above for the purposes of 
advance a deep critical awareness of curriculum purposes in societies with democratic ideals. In addition to four graduate-level classes culminating in a Teacher Leader Endorsement for 40 lead teachers, all administrators in the two districts were to obligate $15 \mathrm{~h}$ of professional learning to gain insights about teacher leadership and create an action plan to support the teacher leaders when they returned to the building. Several suburban schools showed interest but one particular school volunteered immediately. We met with the district team of the suburban district and then with the entire administrative staff including all central office, all building principals, and assistant principals. They embraced the research goals with enthusiasm. Unfortunately, we did not have the same enthusiasm from urban districts. After spending weeks and months recruiting three different urban districts, the fourth one was fully on board. We learned that due to the accountability pressures urban districts experience, time spent on teacher leadership was considered a distraction from the real work of getting kids to pass the test. The superintendent of the fourth district we recruited was very eager to be a part of the grant as was their entire administrative team. Thus we moved forward with the commitment from two districts, one urban and one suburban, to implement a teacher leadership initiative including professional learning for administrators to support a culture of change.

We are in the process of creating the curriculum for four separate workshops over a 3-month time period for all administrators from both districts to meet and share ideas. The goals of these workshops are as follows:

- Create an action plan for teacher leadership in their building/district

- Define teacher leadership (with roles and responsibilities that support district goals that meet the learning needs of students).

- Understand and support 3S curriculum design principles

- Explore ways to establish a culture in the building/district to support teacher leaders

Prior to the meetings, a culture survey was electronically distributed to all employees in both districts. Interestingly, even with the diverse backgrounds of the two districts, the highest level of disagreement in both districts was with the statement "Our school has a trusting environment where teachers feel free to share opinions even if they may be controversial". This seemed to resonate with the administrators during the first administrative workshop and sparked deep discussion in both districts. Using the survey data, administrators will choose two specific areas of need in support of cultural change and create an action plan for teacher leadership in the district and then in the buildings. The administrators will be asked to define teacher leadership, brainstorm ways teacher leaders could support the goals and objectives of the district, and create a culture of support in the buildings. As we conclude this chapter, we are entering into the second professional learning workshop for these administrative leaders. 


\section{Conclusion}

This chapter presents interpretations of teacher and administrative leadership that emerge out of 25 years of action research in a graduate course introducing the fundamentals of curriculum - a topic that lies at the heart of educational practice. What if this FoC course never existed? What if the teachers and administrators who enrolled in the course were introduced instead to an uncritical appraisal of Tylerian fundamentals? In more general terms, what if societies with democratic aspirations didn't have critically-astute, ethically-aware educators to advance their ideals? What if these societies did not have educators who embodied and enacted critical pragmatism, democratic hermeneutics, and holistic pedagogy? What if these educators could not imagine becoming lead professionals for democratic ethics? What if these societies did not have educators who were engaged in personal journeys of ethical becoming? What if, instead, these educators practiced an ideologically rigid, faddishly narrow, vulgar pragmatism? What would be the future of these societies, and could they become "deep democracies" (Green 1999)? As rector of the University of St. Andrews, John Stuart Mill (1867) declares in an inaugural address at his school: "Bad men need nothing more to compass their ends, than that good men should look on and do nothing" (p. 36). As authors of this collaborative chapter, we passionately believe that those with undemocratic ends-in-view will not prevail in societies that are serviced by democratically committed educators. This is the vocational calling, the curricular platform, and the educational leadership we are advancing.

\section{References}

Apple, M. J. (2004). Controlling the work of teachers. In D. J. Flinders \& S. J. Thornton (Eds.), The curriculum studies reader (2nd ed., pp. 183-197). New York: Routledge Falmer. (Original work published 1986).

Apple, M. W. (2005). Education, markets, and an audit culture. Critical Quarterly, 47(1-2), 11-29.

Apple, M. W. (2006). Educating the "right" way: Markets, standards, God, and inequality (2nd ed.). New York: Routledge.

Autio, T. (2006). Subjectivity, curriculum, and society. New York: Routledge.

Autio, T. (2009). From Gnosticism to globalization: Rationality, trans-Atlantic curriculum discourse, and the problem of instrumentalism. In B. Baker (Ed.), New curriculum history (pp. 69-95). Rotterdam: Sense Publishers.

Autio, T. (2015). Tero's R2 and R3 contributions. In J. G. Henderson (Ed.), Reconceptualizing curriculum development: Inspiring and informing action (pp. 180-181, 194-195). New York: Routledge.

Ayers, W. C. (2010). The standards fraud. In A. S. Canestrari \& B. A. Marlowe (Eds.), Educational foundations: An anthology of critical readings (2nd ed., pp. 183-186). Los Angelos: Sage Publications. Original work published in 2000.

Barth, R. S. (2008). Foreword. In G. A. Donaldson (Ed.), How leaders learn: Cultivating capacities for school improvement (pp. ix-xi). New York: Teachers College Press.

Bernier, N. R., \& Williams, J. E. (1973). Beyond beliefs: Ideological foundations of American education. Englewood Cliffs: Prentice-Hall. 
Block, A. A. (2008). Why should I be a teacher? Journal of Teacher Education, 9(5), 416-427.

Burns, J. M. (1978). Leadership. New York: Harper and Row.

Buzzelli, C., \& Johnston, B. (2002). The moral dimensions of teaching: Language, power, and culture in classroom interactions. New York: Routledge Falmer.

Cherryholmes, C. H. (1988). Power and criticism: Poststructural investigations in education. New York: Teachers College Press.

Cochran, C. E., Mayer, L. C., Carr, T. R., \& Cayer, N. J. (1986). American public policy (2nd ed.). New York: St. Martin's Press.

Commission on the Reorganization of Secondary Education. (1918). Cardinal principles of secondary education. Washington, DC: National Education Association.

Cremin, L. A. (1965). The genius of American education. New York: Vintage.

Dewey, J. (1916). Democracy and education. New York: Macmillan.

Dewey, J. (1933). How we think: A restatement of the relation of reflective thinking to the educative process. Boston: D.C. Heath \& Company. (Original work published 1910).

Dewey, J. (1989). Freedom and culture. Buffalo: Prometheus. (Original work published 1939).

Dewey, J. (2013). My pedagogic creed. In D. J. Flinders \& S. J. Thornton (Eds.), The curriculum studies reader (4th ed., pp. 33-40). New York: Routledge. (Original work published 1897).

Dewey, J., \& Bentley, A. F. (1949). Knowing and the known. Boston: The Beacon Press.

Dweck, C. S. (2008). Mindset: The new psychology of success. New York: Ballantine Books.

Ebels-Dugan, K. (2015). Autonomy as intellectual virtue. In H. Brighouse \& M. McPherson (Eds.), The aims of higher education: Problems of morality and justice (pp. 74-90). Chicago: The University of Chicago Press.

Eisner, E. W. (1994). The educational imagination: On the design and evaluation of school programs (3rd ed.). New York: Macmillan.

Eisner, E. (2001). What does it mean to say a school is doing well? Phi Delta Kappa, 82(2), 367-372.

Frankfurt, H. G. (2005). On Bullshit. Princeton: Princeton University Press.

Freire, P. (1997). Pedagogy of the oppressed. New York: Continuum.

Gadamer, H. G. (1975). Truth and method (G. Barden \& J. Cumming, Eds. \& Trans.). New York: Seabury.

Garrison, J. (1997). Dewey and eros: Wisdom and desire in the art of teaching. New York: Teachers College Press.

Good, J. A. (2006). A search for unity in diversity: The "permanent Hegelian deposit" in the philosophy of John Dewey. Lanham: Lexington Books. Add pages referred to at p 18/replace xx.

Goodwin, D. K. (2005). Team of rivals: The political genius of Abraham Lincoln. New York: Simon \& Schuster.

Gornik, R., \& Samford, W. L. (In press). Into the light: Creating a culture of support for teacher leaders. Lanham: Rowman \& Littlefield.

Green, J. M. (1999). Deep democracy: Community, diversity, and transformation. Lanham: Rowman \& Littlefield.

Greene, M. (1988). The dialectic of freedom. New York: Teachers College Press.

Griest, J., Schneider, J. L., School, S., \& Stagliano, K. (2015). Lead learning stories: A narrative montage. In J. Henderson (Ed.), Reconceptualizing curriculum development: Inspiring and informing action (pp. 139-1168). New York: Routledge.

Hansen, D. T. (1995). The call to teach. New York: Teachers College Press.

Hansen, D. T. (2001). Teaching as a moral activity. In V. Richardson (Ed.), Handbook of research on teaching (4th ed., pp. 826-857). Washington, DC: American Educational Research Association.

Henderson, J. G. (1992). Reflective teaching: Becoming an inquiring educator. New York: Macmillan.

Henderson, J. G. (2001a). Reflective teaching: Professional artistry through inquiry (3rd ed.). Upper Saddle River: Merrill/Prentice-Hall.

Henderson, J. G. (2001b). Deepening democratic curriculum work. Educational Researcher, 30(9), 18-21. 
Henderson, J. G., \& Gornik, R. (2007). Transformative curriculum leadership (3rd ed.). Upper Saddle River: Merrill/Prentice-Hall.

Henderson, J. G., \& Kesson, K. R. (2001). Curriculum work as public intellectual leadership. In K. Sloan \& J. Sears (Eds.), Democratic curriculum theory and practice: Retrieving public spaces (pp. 1-23). Troy: Educator's International Press.

Henderson, J. G., \& Kesson, K. R. (2004). Curriculum wisdom: Educational decisions in democratic societies. Upper Saddle River: Merrill/Prentice-Hall.

Henderson, J. G., et al. (2015). Reconceptualizing curriculum development: Inspiring and informing action. New York: Routledge.

Hooks, B. (1994). Changes in format made Teaching to transgress: Education as the practice of freedom. New York: Routledge.

Kegan, R. (1994). In over our heads: The mental demands of modern life. Cambridge, MA: Harvard University Press.

Kentucky Department of Education [KDE]. (2015, December). Kentucky teacher leadership framework. Retrieved from http://education.ky.gov/teachers/Documents/Kentucky\%20Teacher\%20 Leadership\%20Framework.pdf

Kincheloe, J. L. (2001). Describing the bricolage: Conceptualizing a new rigor in qualitative research. Qualitative Inquiry, 7(6), 679-692.

Kincheloe, J. L., McLaren, P., \& Steinberg, S. R. (2011). Critical pedagogy and qualitative research. In Denzin \& Lincoln (Eds.), The Sage handbook of qualitative research (4th ed., pp. 163-178). Los Angeles: Sage.

Kliebard, H. M. (1992). Forging the American curriculum: Essays in curriculum history and theory. New York: Routledge.

Kowalski, T. J. (2013). The school superintendent: Theories, practice, and cases. Thousand Oaks: Sage Publications. Changes in format made.

Lee, G. C. (1961). Crusade against ignorance: Thomas Jefferson on education. New York: Teachers College Press.

Lieberman, A., \& Friedrich, L. D. (2010). How teachers become leaders: Learning from practice \& research. New York: Teachers College Press.

Macdonald, E., \& Shirley, D. (2009). The mindful teacher. New York: Teachers College Press.

Mill, J. S. (1867). Inaugural address: Delivered to the university of St. Andrews. London: Longmans, Green, Reader, and Dyer.

Miller, J. L. (1990). Creating spaces and finding voices: Teachers collaborating for empowerment. Albany: State University of New York Press.

Nancy, J. (2010). The truth of democracy (P. Brault, \& M. Naas, Trans.). New York: Fordham University Press.

Nichols, J. D. (2011). Teachers as servant leaders. Lanham: Rowman \& Littlefield Publishers.

Noddings, N. (1984). Caring: A feminine approach to ethics and moral education. Berkeley: University of California Press.

Noddings, N. (2007). Philosophy of education (2nd ed.). Boulder: Westview Press.

Noddings, N. (2013). Education and democracy in the 21 st century. New York: Teachers College Press.

Null, J. W. (2008). Curriculum development in historical perspective. In F. M. Connelly (Ed.), The Sage handbook of curriculum \& instruction (pp. 478-490). Los Angeles: Sage Publications.

Null, W. (2011). Curriculum: From theory to practice. Lanham: Rowman \& Littlefield Publishers.

Nussbaum, M. C. (2010). Not for profit: The human development approach. Cambridge, MA: The Belknap Press.

Palmer, P. J. (2007). The courage to teach: Exploring the inner landscape of a teacher's life. San Francisco: Jossey-Bass.

Pinar, W. F. (1994). Autobiography, politics, and sexuality: Essays on curriculum 1972-1992. New York: Peter Lang.

Pinar, W. F. (1999). Response: Gracious submission. Educational Researcher, 28(1), 14-15.

Pinar, W. F. (2006). The synoptic text today and other essays: Curriculum development after the reconceptualization. New York: Peter Lang. 
Pinar, W. F. (2013). Curriculum studies in the United States: Present circumstances, intellectual histories. New York: Palgrave Macmillian.

Pinar, W. F., \& Grumet, M. R. (1976). Toward a poor curriculum. Dubuque: Kendall-Hunt.

Pinar, W. F., Reynolds, W. M., Slattery, P., \& Taubman, P. M. (1995). Understanding curriculum: An introduction to the study of historical and contemporary curriculum discourses. New York: Peter Lang.

Rancière, J. (2010). Dissensus: On politics and aesthetics (S. Corcoran, Ed. \& Trans.). London: Continuum.

Ryan, F. X. (2011). Seeing together: Mind, matter and the experimental outlook of John Dewey and Arthur F. Bentley. Great Barrington: The American Institute for Economic Research.

Sahlberg, P. (2011). Finnish lessons: What can the world learn from educational change in Finland? New York: Teachers College Press.

Sahlberg, P. (2015). Finnish lessons: What can the world learn from educational change in Finland? (2nd ed.). New York: Teachers College Press.

Samford, W. (2015). Deliberative conversation: Cross-paradigm critique. In J. Henderson (Ed.), Reconceptualizing curriculum development: Inspiring and informing action (pp. 85-98). New York: Routledge.

Samford, W. (2016). Out of the dark: A direction for change in education. Eugene: Wipf and Stock.

Schwab, J. J. (1973). The practical 3: Translation into curriculum. School Review, 81, 501-522.

Schwab, J. J. (1978). In I. Westbury \& N. J. Wilkof (Eds.), Science, curriculum, and liberal education. Chicago: The University of Chicago Press.

Schwartz, B., \& Sharpe, K. (2010). Practical wisdom: The right way to do the right thing. New York: Penguin Group.

Sirotnik, K. A. (1999). Making sense of educational renewal. Phi Delta Kappan, 86(8), 606-610.

Tanner, D., \& Tanner, L. (2007). Curriculum development: Theory into practice (4th ed.). Upper Saddle River: Merrill/Prentice-Hall.

Tyler, R. W. (1949). Basic principles of curriculum and instruction. Chicago: University of Chicago Press.

Walker, D. F., \& Soltis, J. F. (2009). Curriculum and aims (5th ed.). New York: Teachers College Press.

Watkins, W. H. (2012). Re-imagining public education. In W. H. Watkins (Ed.), The assault on public education: Confronting the politics of corporate school reform (pp. 189-192). New York: Teachers College Press.

Wraga, W. G. (1999). Extracting sun-beams out of cucumbers: The retreat from practice in reconceptualized curriculum studies. Educational Researcher, 28(1), 4-13.

Ylimaki, R. M. (2011). Critical curriculum leadership: A framework for progressive education. New York: Routledge.

York-Barr, J., \& Duke, K. (2004). What do we know about teacher leadership? Findings from two decades of scholarship. Review of Educational Research, 74(3), 255-316.

Open Access This chapter is licensed under the terms of the Creative Commons Attribution 4.0 International License (http://creativecommons.org/licenses/by/4.0/), which permits use, sharing, adaptation, distribution and reproduction in any medium or format, as long as you give appropriate credit to the original author(s) and the source, provide a link to the Creative Commons license and indicate if changes were made.

The images or other third party material in this chapter are included in the chapter's Creative Commons license, unless indicated otherwise in a credit line to the material. If material is not included in the chapter's Creative Commons license and your intended use is not permitted by statutory regulation or exceeds the permitted use, you will need to obtain permission directly from the copyright holder.

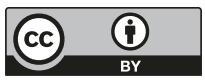

